
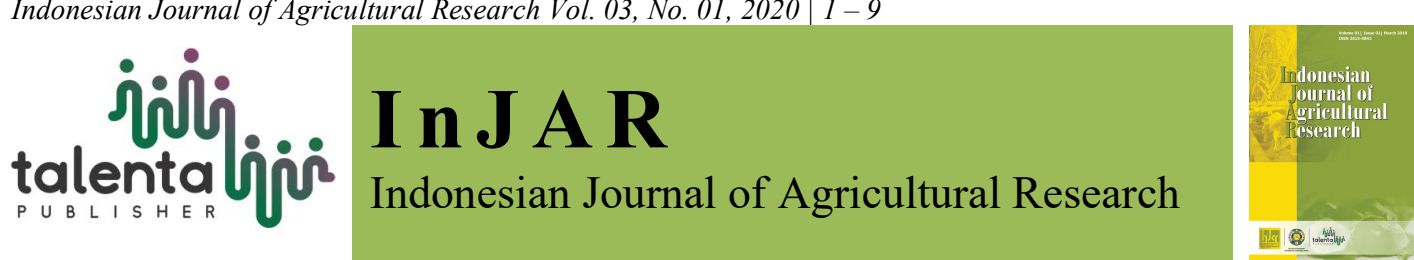

\title{
The Effect of Nutrition Education on Students' Consumption Behavior at Universitas Slamet Riyadi Surakarta
}

\author{
Nanik Suhartatik*, Diyah Ayu Eka Patmasari, Yustina Wuri Wulandari, \\ Akhmad Mustofa, Sri Handayani
}

Fakultas Teknologi dan Industri Pangan Universitas Slamet Riyadi Surakarta, Indonesia

\begin{abstract}
The risk of obesity and chronic diseases rises with the increase in one's level of welfare. Among the influencing factors for such phenomenon are eating behavior and lifestyle. Modern lifestyle which demands that everything be done in an instant makes people consume food with the nutritional adequacy disregarded. The emergence of fast food and junk food in Indonesia has also exerted an influence on people's consumption pattern. Some preventive and mitigating efforts can be made, one of which is provision of nutrition education. This research was aimed to determine the influence of nutrition education on the change of consumption knowledge, behavior, and habit of the students of Universitas Slamet Riyadi Surakarta. The respondents enrolled in this research were of the ages of 19-21 years. They were purposively selected on the basis that some of them were able to plan and select which food to be consumed. This research employed questionnaires during pre-test and posttest, with the respondents assigned to 2 groups of 32 students each. The first group received nutrition education, while the second received none. Results showed that the provision of nutrition education for college students didn't influence students' knowledge, attitude, and behavior when consuming food for both groups. The preference of the student college to food consumption probably influenced by another factors. It would need another study to evaluated factors that influenced the food preference of student college.
\end{abstract}

Key words: behavior, healthy food, junk food, nutrition education, student college

Received 24 January 2020 | Revised 13 February 2020 | Accepted 12 March 2020

\section{Introduction}

The health and knowledge of human beings are inextricably linked to the quality of the food consumed. Food is said to be healthy when it meets the requirement that it must be complete and safe for human consumption. Modern lifestyle which demands that everything be done in an instant makes people consume food with the nutritional adequacy disregarded. Consumption of food with no regard to nutritional adequacy may lead to problems such as obesity and chronic diseases [1].

\footnotetext{
*Corresponding author at: Fakultas Teknologi dan Industri Pangan Universitas Slamet Riyadi Surakarta, J1. Sumpah Pemuda No.18 Joglo, Kadipiro, Surakarta, 57136, Indonesia

E-mail address: n_suhartatik@yahoo.com

Copyright (C) Indonesian Journal of Agricultural Research 2020 Published by Talenta Publisher p-ISSN: 2622-7681 | e-ISSN: 2615-5842 | DOI 10.32734/injar.v2i3.3602

Journal Homepage: https://talenta.usu.ac.id/InJAR
} 
Overweight and obesity refer to a condition which is influenced by several lifestyle factors, namely environmental, behavioral, psychological, physiological, social, and genetic factors [2]. The prevalence of childhood obesity in Indonesia is high with nearly $10 \%$ to $20 \%$ of the children and adolescents [3] [4]. Obesity per se is a multi-factoral disorder linked to a wide variety of important diseases like diabetes, hypertension and other cardiovascular diseases, osteoarthritis, and certain cancers [1]. It arises as a serious issue across the globe not only among adults but also among children and adolescents [5].

Nutrition education contributes to one's attitude and behavior in choosing food [6]. It was presumed that good nutrition education influence food consumption in a positive way and thus generate favorable nutritional status. Indeed, lack of nutrition knowledge and failure to choose appropriate food would influence the nutritional status of a person.

The introduction of junk food to Indonesia has significantly affected the dietary habit of teens in urban areas. Undeniably, the urban lifestyle that favors practicality in all aspects of life makes it a challenge for students to evade junk food. High rates of junk food consumption is attributable to a number of factors, one of which is intense television advertising [7]. Junk food is a term for food which contains a limited amount of nutritional content [1]. It is high in calorie, fat, sugar, and sodium $(\mathrm{Na})$ but low in fiber, vitamin $\mathrm{A}$, ascorbic acid, calcium, and folate. Excessive consumption of junk food may trigger overweight [8]. Inbalanced nutritional contents which have already been consumed at any time, forming a dietary habit, will negatively affect the nutritional status of a person.

Research by Anderson [5] revealed that the chance of obesity in respondents 18-24 years of age who consumed junk food fewer than twice or thrice a week $(60 \%)$ and more than thrice a week $(81 \%)$ was higher than those who did fewer than once a week. Meanwhile, research by Sungkowo and colleagues on adolescents showed a significant difference between the average value of food and nutrition knowledge before and after intervention for treatment group. Before the intervention, the value was considered low (51.92\%), and after the intervention, the value improved and was considered good (75.13\%).

College students of Slamet Riyadi University were engaged in busy activities in general. The campus location was in an urban area and in close proximity to a vast array of junk food restaurants and its state of being surrounded by various food booths allowed the students wider options of junk foods. Reasons for consuming foods sold around the campus such as being timeeffective, tasty, easy to access, cheap, and filling were the main drivers for the students to favor fast food and junk food [9]. It was exacerbated by modern lifestyle that demands instantenousness in all aspects of life, the students' living far from their parents, giving them the freedom to choose which food to be consumed, and the students' giving little attention to nutritionally balanced dietary behavior. 
The students' conditions and the students themselves serve as the drivers or the promoters in the community, requiring education to raise awareness of healthy dietary habits and to suppress degenerative diseases. Appropriate education methods or techniques are thus important to the realization of healthier, smarter Indonesia. The aims of this research were to determine the influence of the provision of nutrition education on nutrition knowledge and junk food consumption behavior and to determine the relationship between nutrition knowledge and the fast food consumption frequency of the students of Universitas Slamet Riyadi Surakarta. The present study is part of a larger inquiry conducted on elementary school, junior high school, and senior high school students.

\section{Materials and Methods}

This study was carried out in March 2019 involving a number of sources who provided the education. Education provision was performed four times: education 1 on balanced nutrition; education 2 and 3 on functional foods; and education 4 on food safety. The main objective or focus of this research was nutrition education and its influences on the behavior and frequency of fast food consumption of the students of Universitas Slamet Riyadi Surakarta. The students' dietary habit was affected by lifestyle, economic status, and easy access of the diet in the immediate environment, while the low level of the students' knowledge of the harm of consuming junk food had led this unhealthy diet to mushroom among a vast majority of them.

This research was an experimental experiment, prospective study to examine the effect of nutrition education on students' knowledge and behavior [10]. The main goals of the study was lowering the prevalence of obesity in Indonesia by finding methods to change food habits, especially to decline junk food consumption.

The respondents enrolled consisted of 2 groups of 32 students each. One group was given knowledge (nutrition education), while the other was not. Both groups were enrolled from the same campus to avoid sociocultural and economic differences.

This research employed questionnaires which were divided into 4 sections: 8 questions on the participants' demographic conditions; 5 questions (true-false) on junk food knowledge; 7 questions on attitude (habit); and questions on how frequently the participants consumed junk foods like tortilla, potato chips, cassava chips, chocolate, soda, packaged beverages, and traditional meat ball ("cilok").

The questionnaires used for testing were previously subjected to testing of fitness on 32 randomly selected students. The test was carried out by looking into the responses to the questionnaires and by accommodating questions, commentaries, and complaints from the students. This test of fitness was followed by a validity test involving 6 experts ( 3 teachers, 1 expert in the field of public health, 1 official of the Office of Health, and 1 food expert in the field of education. Data 
were collected from pre-test and post-test. Nutrition education was provided for one of the two groups after the pre-test. The education materials were delivered four times within a period of 1 month.

The materials in each session were delivered once a week for a duration of 45-90 minutes. Posttest data were collected 2 months after the delivery of the last material to see the effectiveness and efficiency of the education. The collected data were then analyzed using the SPSS program through an ANOVA test.

\section{Results and Discussion}

As many as 64 students were involved in this study, consisting of 47 males (87.5\%) and 17 females (12.5\%), aged 19-20 years. According to [11], these students belonged to the adolescent and young adult age category. The students of Slamet Riyadi University of Surakarta were predominantly students of upper-middle class as proven by the amount of allowance provided in the questionnaires distributed. The first section of the questionnaires stated the students' junk food knowledge. According to the results the group receiving nutrition education demonstrated a significant difference between pre-test and post-test, while the other group did not. Every part of these questionanires was intended to figure out the students' knowledge of healthy food, unhealthy food (junk food), and fulfillment of nutritional adequacy. The groups to which nutrition education treatment was administered provided different opinions on junk food before and after the provision of nutrition education, in particular for the statements "junk food cannot be consumed in place of breakfast" and "junk food is a healthy food."

Table 1. Reason for junk food consumption

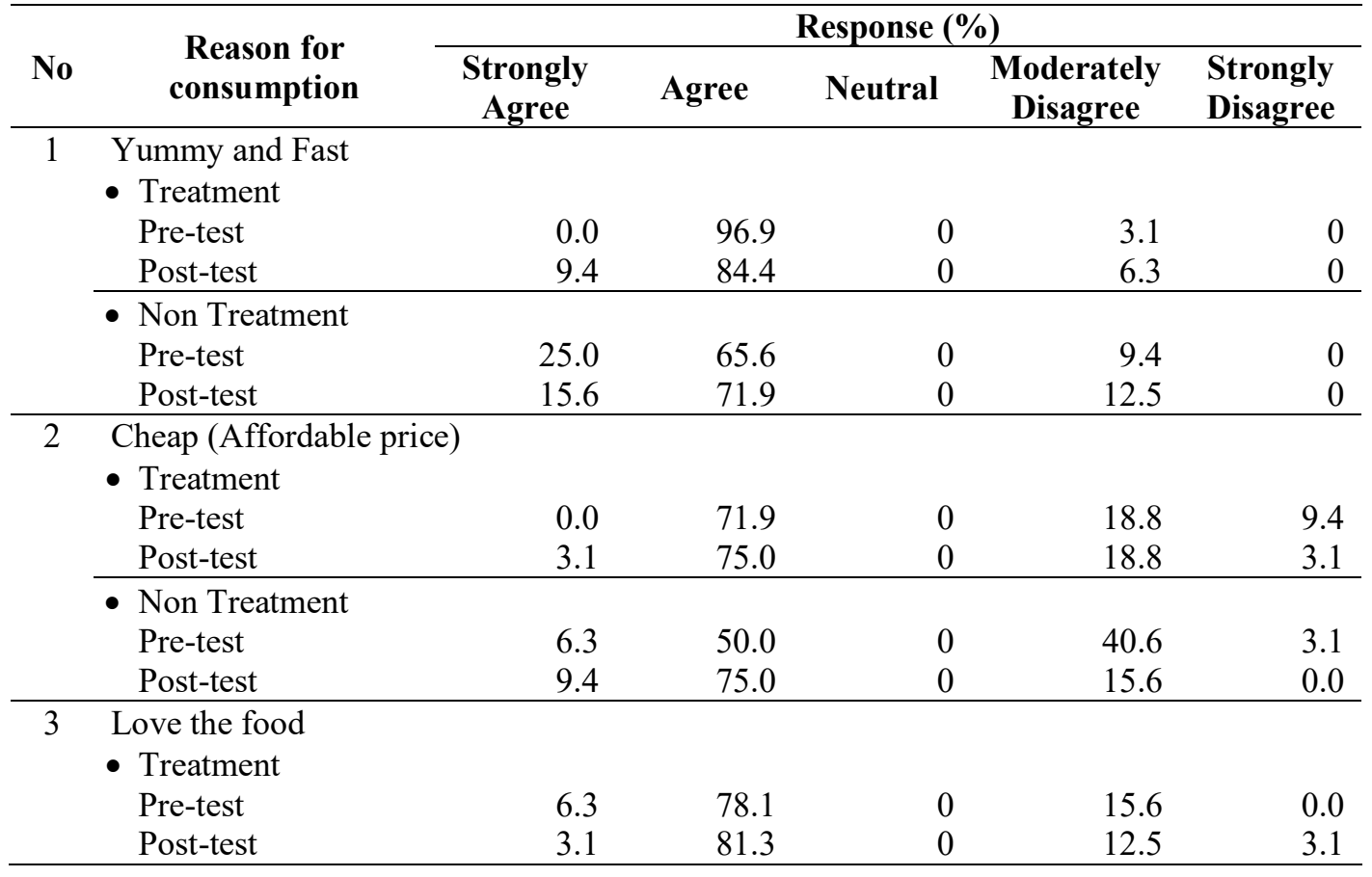


Table 1. Continued

\begin{tabular}{|c|c|c|c|c|c|c|}
\hline \multirow[b]{2}{*}{ No } & \multirow{2}{*}{$\begin{array}{l}\text { Reason for } \\
\text { consumption }\end{array}$} & \multicolumn{5}{|c|}{ Response (\%) } \\
\hline & & $\begin{array}{l}\text { Strongly } \\
\text { Agree }\end{array}$ & Agree & Neutral & $\begin{array}{l}\text { Moderately } \\
\text { Disagree }\end{array}$ & $\begin{array}{l}\text { Strongly } \\
\text { Disagree }\end{array}$ \\
\hline \multirow[t]{3}{*}{3} & - Non Treatment & & & & & \\
\hline & Pre-test & 12.5 & 65.6 & 0 & 21.9 & 21.9 \\
\hline & Post-test & 18.8 & 62.5 & 0 & 18.8 & 0.0 \\
\hline \multirow[t]{7}{*}{4} & Easy to find & & & & & \\
\hline & - Treatment & & & & & \\
\hline & Pre-test & 18.8 & 78.1 & 0 & 3.1 & 0 \\
\hline & Post-test & 21.9 & 78.1 & 0 & 0 & 0 \\
\hline & - Non treatment & & & & & \\
\hline & Pre-test & 12.5 & 84.4 & 0 & 3.1 & 0 \\
\hline & Post-test & 21.9 & 71.9 & 0 & 6.3 & 0 \\
\hline \multirow[t]{7}{*}{5} & Be like my idol & & & & & \\
\hline & - Treatment & & & & & \\
\hline & Pre-test & 0 & 6.3 & 0 & 75.0 & 18.8 \\
\hline & Post-test & 0 & 15.6 & 0 & 78.1 & 6.3 \\
\hline & - Non treatment & & & & & \\
\hline & Pre-test & 28.1 & 56.3 & 0 & 3.1 & 0 \\
\hline & Post-test & 18.8 & 75.0 & 0 & 6.3 & 0 \\
\hline \multirow[t]{7}{*}{6} & Big Portion & & & & & \\
\hline & - Treatment & & & & & \\
\hline & Pre-test & 6.3 & 25.0 & 0 & 62.5 & 6.3 \\
\hline & Post-test & 3.1 & 21.9 & 0 & 75.0 & 0.0 \\
\hline & - Non treatment & & & & & \\
\hline & Pre-test & 3.1 & 31.3 & 0 & 65.6 & 0.0 \\
\hline & Post-test & 6.3 & 25.0 & 0 & 65.6 & 3.1 \\
\hline \multirow[t]{7}{*}{7} & Good Advertisment & & & & & \\
\hline & - Treatment & & & & & \\
\hline & Pre-test & 3.1 & 43.8 & 0 & 50.0 & 3.1 \\
\hline & Post-test & 3.1 & 56.3 & 0 & 34.4 & 6.3 \\
\hline & - Non treatment & & & & & \\
\hline & Pre-test & 9.4 & 46.9 & 0 & 43.8 & 0 \\
\hline & Post-test & 6.3 & 53.1 & 0 & 40.6 & 0 \\
\hline
\end{tabular}

The second section of the questionnaires was intended to figure out the respondents' behavior toward junk food. In this section, the respondents were asked to rank 6 types of foods and beverages belonging to the junk food category and to provide rationale for their choices. Food included in the junk food category were potato chips, pizza, grilled meatball, chicken, chocolate, and soft drink. As many as $12.5 \%$ of the respondents who received nutrition education were in favor of pizza as their favorite food during the pre-test, and the percentage dropped to $6.3 \%$ during the post-test. Based on the results of the statistical analysis, nutrition education did not influence the choice of favorite food or the frequency of junk food consumption.

The majority of the respondents chose to consume junk foods because the foods were tasty and fast-delivered, affordable, easy to find, and served in a big portion, because they wanted to imitate others, and because the advertisement was interesting (Table 2). These reasons were in line with the ones found by [9], namely, because the foods were tasty, because consuming the foods was practical, and because the foods held a high prestige among students. According to the results 
obtained from the treatment group, $18.8 \%$ of the respondents disagreed with the statement that junk foods were affordable, $78.1 \%$ disagreed with the statement that they consumed junk foods to imitate others, $75.0 \%$ disagreed with the statement that they consumed junk foods because they were served in a relatively large portion, and $34.4 \%$ disagreed with the statement that they consumed junk food because of the advertisement. Nutrition education seemed to affect the reasons for the respondents' choosing to consume junk foods.

Table 2. Respondent behavior toward Food Product (group with education treatment)

\begin{tabular}{|c|c|c|c|c|c|c|}
\hline \multirow[b]{2}{*}{ No } & \multirow[b]{2}{*}{ Condition } & \multicolumn{5}{|c|}{ Response (\%) } \\
\hline & & $\begin{array}{c}\text { Strongly } \\
\text { Agree }\end{array}$ & Agree & Neutral & $\begin{array}{c}\text { Moderately } \\
\text { Disagree }\end{array}$ & $\begin{array}{l}\text { Strongly } \\
\text { Disagree }\end{array}$ \\
\hline \multirow[t]{3}{*}{1} & Reading the labels & & & & & \\
\hline & Pre-test & 3.1 & 75.0 & 0 & 21.9 & 0 \\
\hline & Post-test & 9.4 & 65.6 & 0 & 25.0 & 0 \\
\hline \multirow[t]{3}{*}{2} & Mood booster & & & & & \\
\hline & Pre-test & 0 & 37.5 & 0 & 59.4 & 3.1 \\
\hline & Post-test & 3.1 & 43.8 & 0 & 50.0 & 3.1 \\
\hline \multirow[t]{3}{*}{3} & Nutrition value & & & & & \\
\hline & Pre-test & 21.9 & 75.0 & 0 & 3.1 & 0 \\
\hline & Post-test & 9.4 & 84.4 & 0 & 6.3 & 0 \\
\hline \multirow[t]{3}{*}{4} & Junk food supply chain & & & & & \\
\hline & Pre-test & 9.4 & 78.1 & 0 & 12.5 & 0 \\
\hline & Post-test & 12.5 & 78.1 & 0 & 9.4 & 0 \\
\hline \multirow[t]{3}{*}{5} & Government program & & & & & \\
\hline & Pre-test & 3.1 & 59.4 & 0 & 37.5 & 0 \\
\hline & Post-test & 6.3 & 56.3 & 0 & 37.5 & 0 \\
\hline
\end{tabular}

The results obtained from the non-treatment group showed that $71.9 \%$ of the respondents agreed that junk foods are tasty and fast-delivered, 50\% stated that junk foods were accessible at affordable prices during the pre-test and more than $25 \%$ more stated so during the post-test, $75.0 \%$ stated they wanted to imitate others, $75.0 \%$ disagreed that junk foods were served in a large portion, and $53.1 \%$ agreed that advertisements influenced their choise to consume junk foods.

Based on the results, $43.8 \%$ of the respondents from the treatment group agreed and $50.0 \%$ disagreed that consuming junk foods would influence their mood. The percentage of respondents who agreed with the statement that attention should be paid to the nutritional adequacy of junk foods increased after the provision of nutrition education from $75.0 \%$ during the pre-test to $84.4 \%$ during the post-test. This suggests that the respondents receiving the treatment of nutrition education experienced a change in behavior toward junk food.

The results from the non-treatment group showed that $40.6 \%$ of the respondents disagreed that consuming junk food would influence mood. The percentage of the respondents $(21.9 \%)$ did not undergo any improvement from pre-test to post-test in the statement that the activities initiated by the government (Office of Health, Office of Education, Public Health Center/puskesmas, etc.) exhibited positive outcome toward the circulation of junk foods. This suggests that the 
respondents from the non-treatment group did not undergo any change in behavior toward junk food.

Table 3. Respondent behavior toward Food Product (group without education treatment)

\begin{tabular}{|c|c|c|c|c|c|c|}
\hline \multirow[b]{2}{*}{ No } & \multirow[b]{2}{*}{ Conditions } & \multicolumn{5}{|c|}{ Response (\%) } \\
\hline & & $\begin{array}{l}\text { Strongly } \\
\text { Agree }\end{array}$ & Agree & Nuetral & $\begin{array}{c}\text { Moderately } \\
\text { Disagree }\end{array}$ & $\begin{array}{l}\text { Strongly } \\
\text { Disagree }\end{array}$ \\
\hline \multirow[t]{3}{*}{1} & Read the nutrition value & & & & & \\
\hline & Pre-test & 15.6 & 75.0 & 0 & 6.3 & 3.1 \\
\hline & Post-test & 9.4 & 71.9 & 0 & 15.6 & 3.1 \\
\hline \multirow[t]{3}{*}{2} & Mood Booster & & & & & \\
\hline & Pre-test & 6.3 & 46.9 & 0 & 40.6 & 6.3 \\
\hline & Post-test & 6.3 & 50.0 & 0 & 40.6 & 3.1 \\
\hline \multirow[t]{3}{*}{3} & Complete Nutrition & & & & & \\
\hline & Pre-test & 31.3 & 65.6 & 0 & 3.1 & 0 \\
\hline & Post-test & 21.9 & 68.8 & 0 & 9.4 & 0 \\
\hline \multirow[t]{3}{*}{4} & junk food distribution & & & & & \\
\hline & Pre-test & 18.8 & 75.0 & 0 & 6.3 & 0 \\
\hline & Post-test & 15.6 & 68.8 & 0 & 15.6 & 0 \\
\hline \multirow[t]{3}{*}{5} & Govermental Program & & & & & \\
\hline & Pre-test & 9.4 & 68.8 & 0 & 21.9 & 0 \\
\hline & Post-test & 18.8 & 59.4 & 0 & 21.9 & 0 \\
\hline
\end{tabular}

The third section of the questionnaires concerned how frequently the respondents consumed foods or beverages which belonged to the junk food category (Tables 4 and 5). Drinks included in the category for beverages were fruit-flavored drink, energy drink, sweet bottled drink (Pocari Sweat, tea, coffee, Thai tea, Dum Dum, etc.), sport drink, ice cream, and soda. As for foods, the category included fast food (Pizza Hut, McDonalds, Popeye, Olive, Fried Chicken, etc.), potato/corn chips, sweet food (chocolate, candy, cupcake), fresh fruit, vegetable, and cookies. In the beverage category, frequency generated a significant difference between pre- and post-test only in energy drink.

During the pre-test, the respondents of the treatment group (those who received nutrition education) had a high tendency to consume energy drink and sweet bottled drink, but the tendency decreased during the post-test. This shows that nutrition education successfully altered the level of drink consumption.

The foods frequently consumed by the students were sweet food, fresh fruit, and vegetable. The three types of food were consumed nearly every day by the majority of the repondents. The three other types of food - fast food, potato/corn chips, and cookies - counted as rarely consumed foods; the frequency ranged from 3 or 4 times a week to rare. Although nutrition education did not affect the respondents' preference for food types, most respondents decided to read the nutrition label prior to purchasing the food.

Students who lived separately from their families had more freedom to choose which food to eat. They tended to favor fast food as it is more cost-effective, faster, easier to access, and economical. Many student consumers overlooked the nutritional value of the food consumed. It can be said that college years count as "late" for students to receive nutrition education. Aside from reasons like psychological age, students had established a strong principle, causing it hard for them to 
make a change to their behavior. There was no significant relationship between basic knowledge and rationality of consumption of S1 program students of Untan's Faculty of Teacher Training and Education. However, Abraham [9] stated that in fact character education in college years was able to refine the character already formed in students through previous education.

Several types of food and beverage were found to undergo a decrease in consumption after the provision of nutrition education. The beverages frequently consumed were energy drink and sweet bottled drink. Sweet bottled drink was more often consumed than other types of beverages at a frequency of 1-4 times a week. Other beverages like sport drink, ice cream, fruit-flavored drink, and soda were rarely consumed. In general, the respondents who were aged 19-21 years had been aware that these beverages were to be consumed only when needed.

The students were highly in favor of consuming junk food due to several supporting factors like lifestyle and the tendency of the students to prefer something instant, fast, easy, and cheap. Factors that influenced one's knowledge and attitude was media. Exposure of unhealthy food advertisements on TV shows may contribute to overweight and obesity [12]. It is thus recommended that the government make efforts to reduce the quantity of junk food advertising and that education on healthy lifestyle be provided.

\section{Conclusions}

Provision of nutrition education influenced the knowledge, behavior, and habit of the respondents from Slamet Riyadi University of Surakarta. Nutrition education had successfully altered the respondents' view on the consumption of junk food, energy drink, and sport drink. The respondents consumed junk food because it was fast, tasty, affordable, easy to access, and served in a larger portion. However, the view on junk food was not significantly affected in those who did not receive nutrition education.

\section{Acknowledgments}

This research was funded by the General Ministry of Higher Education trough Fundamental Research Grant (Penelitian Dasar). Special thanks to the research team and Health Department of Surakarta District for the advisor and support.

\section{REFERENCE}

[1] S. Misra and M. Pathania, "Evaluation of the Effect of junk food on the health of the school children in Delhi," Department of Consumer Affairs, Ministry of Consumer Affairs, Food \& Public Distribution Government of India, New Delhi, 2016.

[2] J. Q. Purnell, "Definitions, Classification, and a epidemiology of obesity," South Darmouth: National Library of Medicine, 2018. [Online] Available: https://www.ncbi.nlm.nih.gov/books/NBK279167/?report=printable 
[3] General Ministry of Health, "Riset Kesehatan Dasar (RISKESDA)," Badan Penelitian dan Pengembangan Kesehatan, 2013.

[4] D. A. Chandra, A. E. Manampiring, and Fatimawali, "Prevalensi obesitas pada remaja SMA YPKM di Kota Manado," J e-Biomedik, vol. 2, no. 2, 2014.

[5] B. Anderson, A. P. Rafferty, S. Lyon-Callo, C. Fussman, and G. Ime, "Fast-food consumption and obesity among Michigan adults," Prev Chronic Dis, vol. 8, no. 4:A71, 2011. [Online]. Available: http://www.ncbi.nlm.nih.gov/pubmed/21672395\%0Ahttp://www.pubmedcentral.nih.gov/ar ticlerender.fcgi? artid=PMC3136980.

[6] T. Mahmudiono, T. S. Nindya, D. R. Andrias, H. Megatsari, and R. R. Rosenkranz, "The effectiveness of nutrition education for overweight/obese mothers with stunted children (NEO-MOM) in reducing the double burden of malnutrition in Indonesia: study protocol for a randomized controlled trial," BMC Public Health, vol. 16, no. 486, 2016.

[7] J. Lee, S. Jeong, G. Ko, H. Park, and Y. Ko, "Development of a food safety and nutrition education program for adolescents by applying social cognitive theory," Osong Public Heal Res Perspect, vol. 7, no. 4, pp. 248-260, 2016. [Onlie]. Availabl: http://dx.doi.org/10.1016/j.phrp.2016.05.005.

[8] M. F. Oginsky, P. B. Goforth, C. W. Nobile, L. F. Lopez-Santiago, and C. R. Ferrario, "Eating 'Junk-food' produces rapid and long-lasting increases in NAc CP-AMPA receptors: Implications for enhanced cue-induced motivation and food addiction," Neuropsychopharmacology, vol. 41, no. 13, pp. 2977-86, 2016. [Online]. Available: http://dx.doi.org/10.1038/npp.2016.111.

[9] S. Abraham, B. R. Noriega, and J. Y. Shin, "College students eating habits and knowledge of nutritional requirements," J Nutr Hum Heal, vol. 2, no. 1, pp. 13.17, 2018.

[10] A. Vardanjani, M. Reisi, H. Javadzade, Z. G. Pour, and E. Tavassoli, "The Effect of nutrition education on knowledge, attitude, and performance about junk food consumption among students of female primary schools," J Educ Health Promot, vol. 4, no. 53, 2015. [Online]. Available: http://www.jehp.net/text.asp?2015/4/1/53/162349.

[11] B. Bogin, "Human Growth and Development," in Basics in Human Evolution, M. P. Meuhlenbein, Ed. London: Academic Press, 2015, pp. 285-293.

[12] D. Gilbert-Diamond, et al., "Television food advertisement exposure and FTO rs9939609 genotype in relation to excess consumption in children," Int J Obes. vol. 41, no. 1, pp. 23 29, 2017. 